\title{
Should the Maastricht fiscal criteria be redefined?
}

\author{
ANTO BAJO Institute of Public Finance \\ MARKO PRIMORAC Faculty of Economics and Business Zagreb
}

The Statistical Office of the European Commission, Eurostat, at the beginning of February 2015, released for the first time data on contingent liabilities and non-performing loans of European Union (EU) member states. Contingent liabilities include guarantees, liabilities related to public-private partnerships and liabilities of public corporations that are controlled by the state, but excluded from the statistical coverage of general government. The scale of the contingent liabilities of member states reveals a completely new image of their indebtedness and exposure to fiscal risks, and also raises the issue of the need to redefine the Maastricht fiscal criteria. It is obvious that member states - under pressure from budgetary restrictions (in line with the Maastricht criteria) - are creating liabilities that certainly affect the growth of public debt. At the same time these liabilities were only until recently beyond the reach of Eurostat.

\section{INTRODUCTION}

In order to circumvent the fiscal criteria of the Maastricht Treaty while under the influence of the financial crisis, EU member states have created off-balance sheet contingent liabilities. Given that such liabilities do not affect the level of general government debt and deficit, they have so far gone largely unnoticed. In November 2OII, the European Parliament and the European Council adopted an improved framework for the management of economic policy in the EU (the Enhanced Economic Governance Package -known as the Six-Pack) because it consists of the Council Directive 20II/85/EU and of five regulations ${ }^{\mathrm{I}}$. Among other statistical requirements, the improved framework provided for the collection of data on contingent liabilities, while the Directive imposed the duty of disclosure of the contingent liabilities of all general government sub-sectors. Eurostat requires member states to report the amount and structure of their guarantees, non-performing loans, liabilities related to public-private partnership (PPP) projects and liabilities of public corporations. National statistical institutes annually report information on contingent liabilities to Eurostat (before December 3I) for the previous year. The first delivery of data began in 2014 for 20I3, whereas Eurostat released the first incomplete statistics in January 2015 (see Appendix). Analysis of the amount and structure of contingent liabilities reveals the scope of fiscal risk more realistically and provides a somewhat different picture of the fiscal position of member states.

\footnotetext{
${ }^{\text {I }}$ Regulation II73/20II: On the effective enforcement of budgetary surveillance in the euro area; Regulation II74/2OII: On enforcement action to correct excessive macroeconomic imbalances in the euro area; Regulation II75/2OII amending Regulation I466/97: On the strengthening of the surveillance of budgetary positions and the surveillance and coordination of economic policies; Regulation II76/20II: On the prevention and correction of macroeconomic imbalances and Regulation II77/2OII amending Regulation I467/97: On speeding up and clarifying the implementation of the excessive deficit procedure.
} 


\section{THE GENERAL GOVERNMENT DEBT, DEFICIT AND THE EXCESSIVE DEFICIT PROCEDURE}

Assessment of the fiscal stability or instability of EU member states has until recently been based solely on the analysis of general government direct debt and budget deficit. Thus, the criteria of the Stability and Growth Pact - the Maastricht criteria - focus merely on compliance with the limit (maximum value) of the ratio of consolidated general government debt (6o\%) and deficit (3\%) to GDP. In the aftermath of the financial crisis, fewer and fewer countries are in conformity with the established fiscal criteria and have entered the excessive deficit procedure (EDP). There are currently eleven EU countries in the EDP (Croatia, Malta, Cyprus, Portugal, Slovenia, Poland, France, Ireland, Greece, Spain and the UK), although almost all member states were at some point in the past in the EDP, except Estonia and Sweden.

\section{Figure I}

General government debt of EU member states, 2013 (\% of GDP)

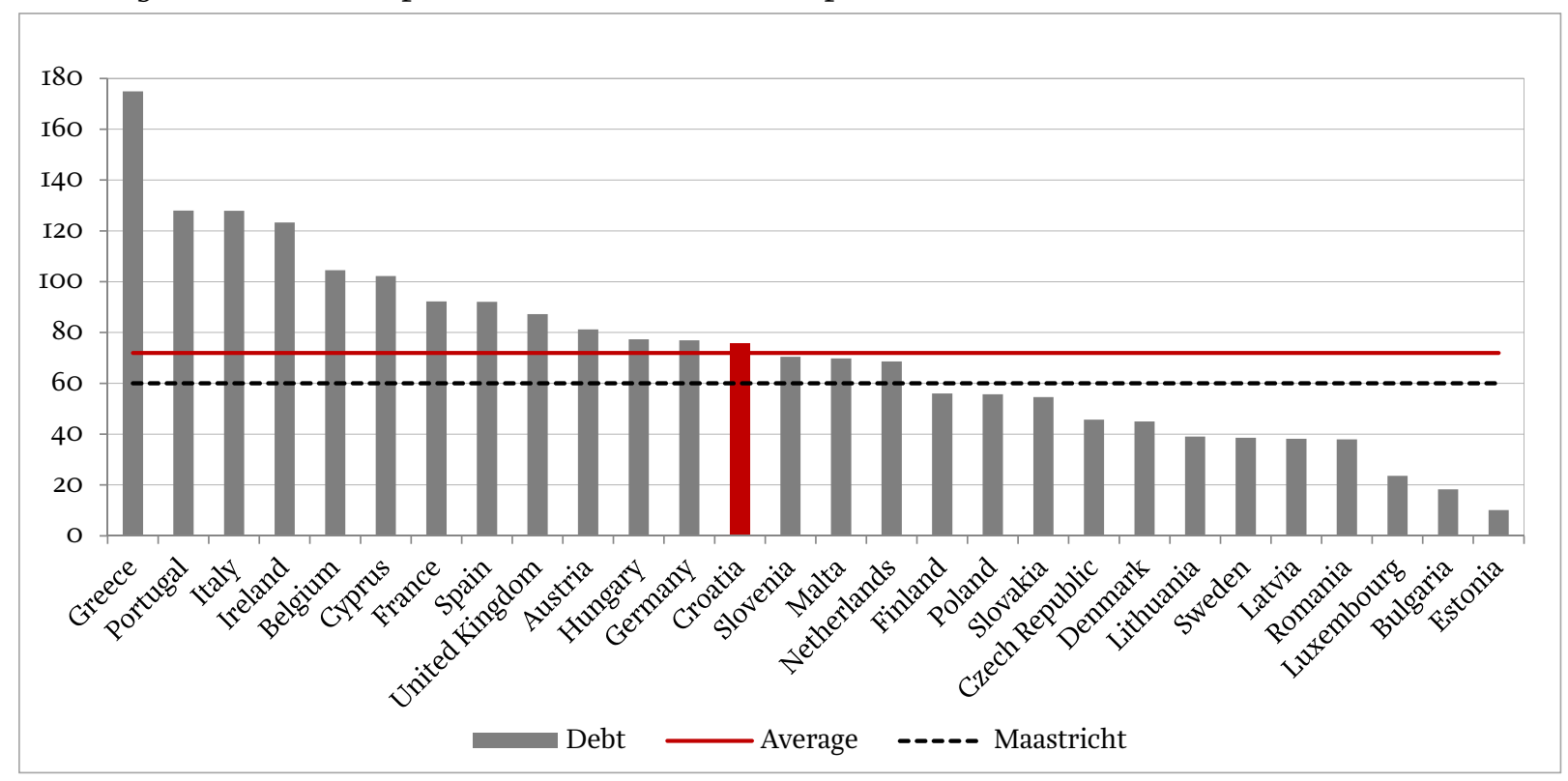

Source: Eurostat

In 20I3, the average share of debt to GDP was $72 \%$; Croatia, with a debt of $75.7 \%$ of GDP, was indebted above the average. Sixteen out of 28 countries had a debt to GDP ratio higher than $60 \%$. The majority of member states, however, were in compliance with the budget deficit criterion. The average budget deficit in 2013 was $3.5 \%$ of GDP, while only ten countries had a deficit higher than $3 \%$ of GDP. The largest consolidated general government deficit in 2013 was recorded in Slovenia (I4.6\%), and Luxembourg was the only member state facing a budgetary surplus, one of o.6\% of GDP.

Data on general government debt and deficit are often used as indicators of the fiscal position of the country. However, member states are exposed to the impact of contingent liabilities, non-performing loans and maturity risk of outstanding liabilities in the PPP contracts and their transformation into public debt (direct liabilities). Therefore, it is reasonable to ask whether it is time to redefine the criteria of the Stability and Growth Pact and include the contingent liabilities in the scope of the public debt. Since these liabilities are recorded off-balance sheet, they are mostly not in the focus of public attention and government policies. 


\section{Figure 2}

General government budget balance in 2013 (\% of GDP)

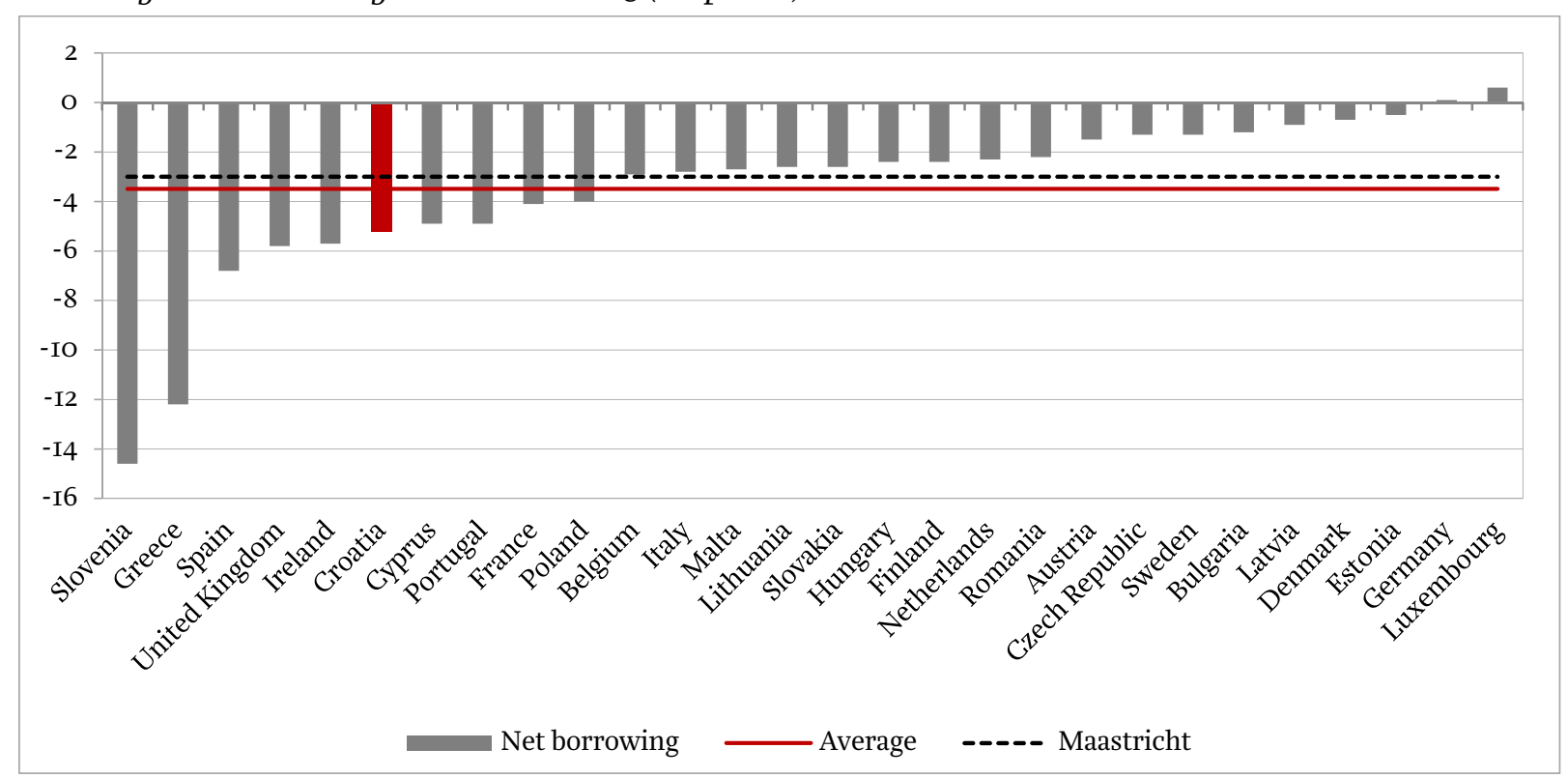

Source: Eurostat

\section{CONTINGENT LIABILITIES}

Contingent liabilities are: guarantees, PPP projects, liabilities of public corporations and nonperforming loans. These liabilities do not fall within the scope of the general government debt according to the Council Regulation (EC) No 479/2009 for the implementation of the Protocol on the Excessive Deficit Procedure annexed to the Treaty Establishing the European Community.

Guarantees are contingent liabilities because the guarantor undertakes to a lender that if a borrower defaults, the guarantor will make good the loss the lender would otherwise suffer. Eurostat collects data on standardized and one-off guarantees. ${ }^{2}$

In 2013, Austria had the largest share of guarantees in GDP (35\%) and Slovakia the lowest (0.03\%). Active guarantees in Croatia amounted to $7.25 \%$ of GDP (lower than the EU average, which stood at $10.5 \%$ of GDP). ${ }^{3}$ If they are called on, guarantees convert from the category of potential into the direct public debt.

\footnotetext{
${ }^{2} \mathrm{~A}$ one-off guarantee is defined as individual, and guarantors are not able to make a reliable estimate of the risk of calls. One-off guarantees are linked to debt instruments (e.g. loans, bonds). Standardised guarantees are guarantees that are issued in large numbers, usually for fairly small amounts, along identical lines. It is not possible to estimate precisely the risk of each loan being in default but it is possible to predict how many, out of a large number of such loans, will default. Examples of standardised guarantees are mortgage loan guarantees and student loan guarantees, whereas examples of one-off guarantees include guarantees for borrowings of public enterprises.

3 This is due to conversion of government guarantees to shipyards, Croatian Motorways and Rijeka-Zagreb Motorway into direct liabilities. The reduction of contingent liabilities resulted in the growth of direct liabilities.
} 


\section{Figure 3}

Total stock of government guarantees in EU member states, 2013 (\% of GDP)

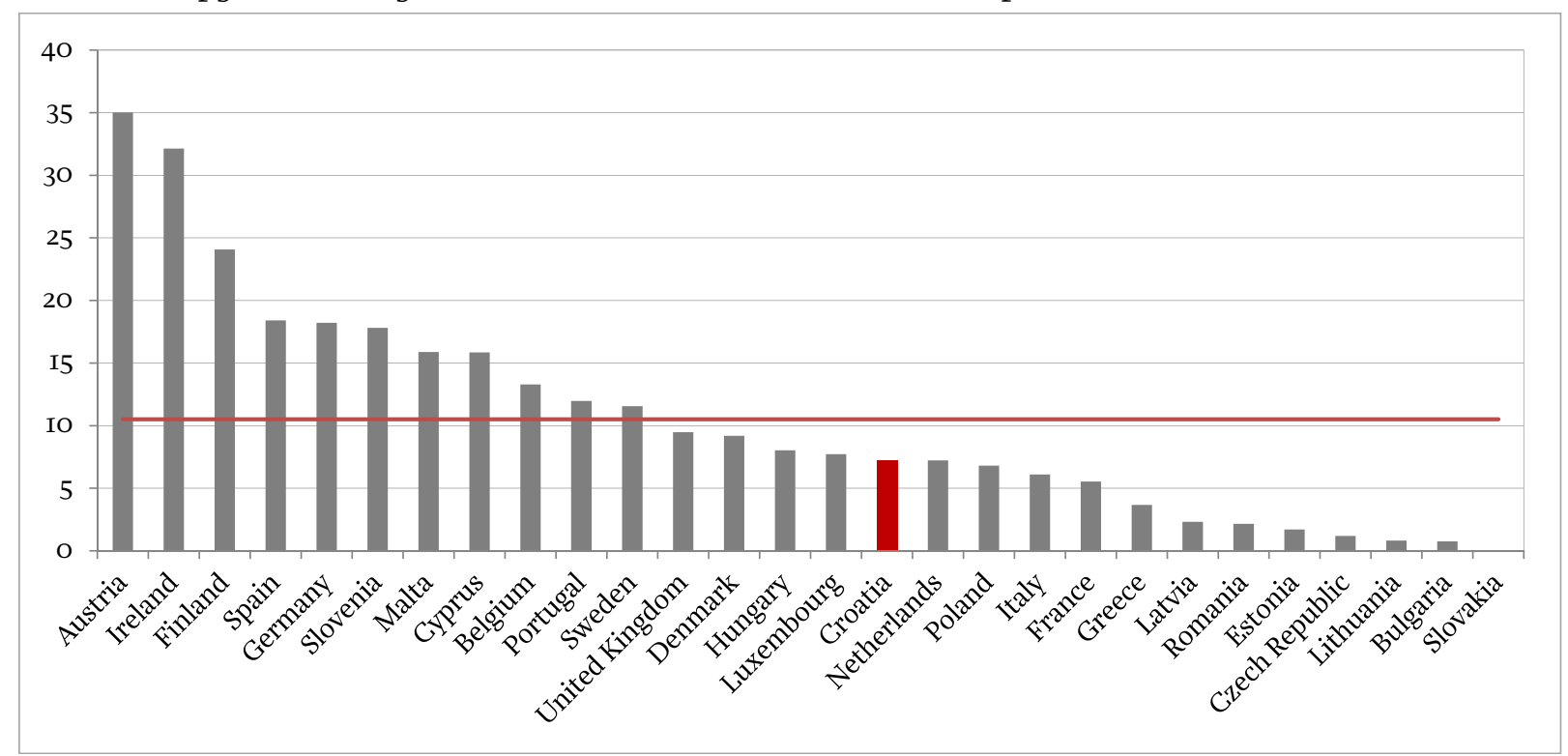

Source: Eurostat

Liabilities of public corporations classified outside general government (public corporations) are defined as the stock of liabilities at the end of the year, based on the business accounts of corporations. Those government controlled entities are classified outside general government due to their behaviour as market units. However, because of the control established over these corporations, it is certain that the government would assume their liabilities if they fell into financial difficulties. Moreover, countries often help such corporations through direct transfers from the budget. Of course, the ability to assume liabilities at the expense of the government's budget directly depends on the economic strength of the country. For example, a problem with bankruptcies of large corporations can more easily be handled in countries with higher than those with lower or below average levels of GDP.

\section{Figure 4}

Total outstanding liabilities of government-controlled entities classified outside the general government, 2013 (\% of GDP)

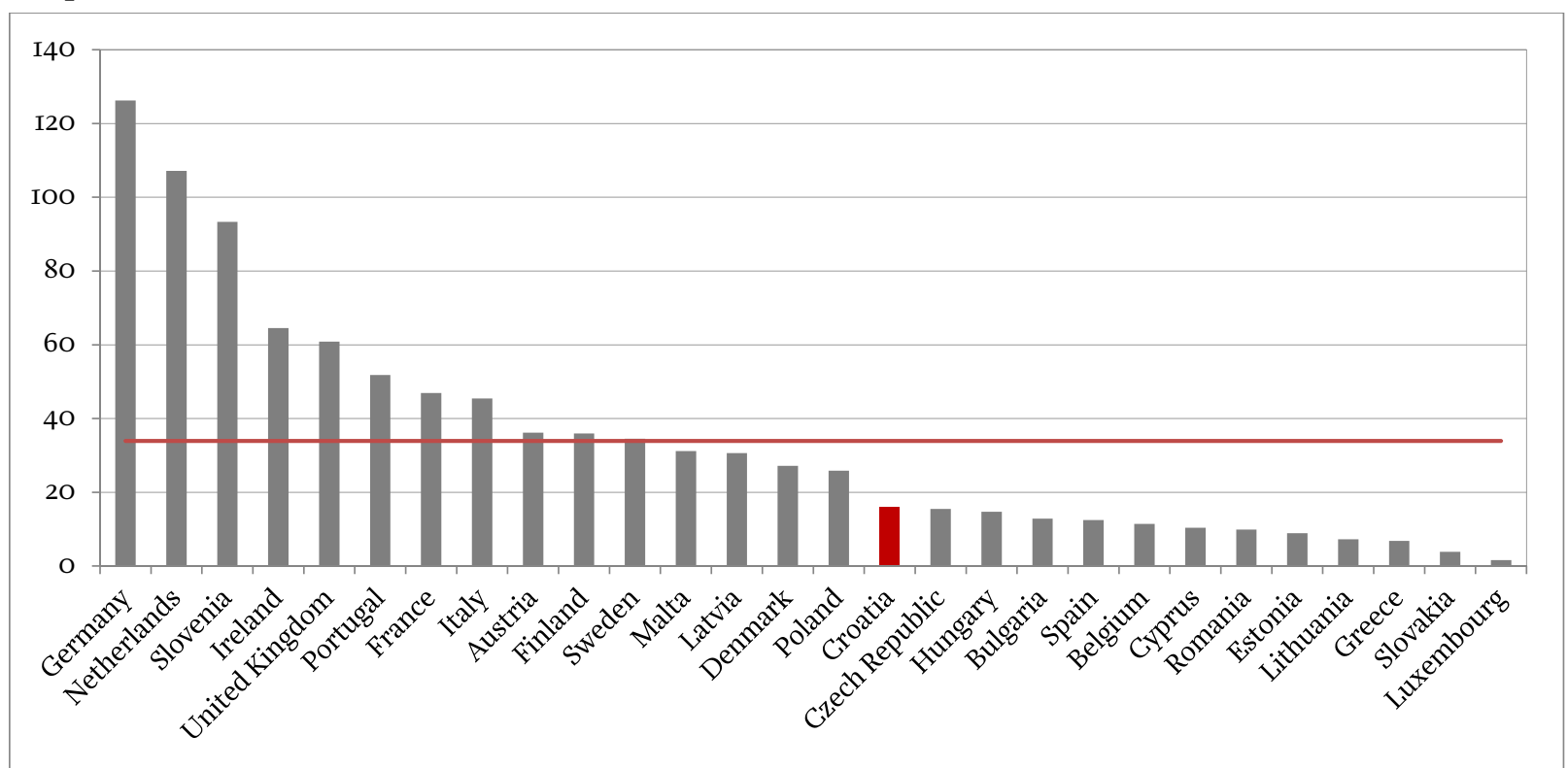

Note: Data for Germany, Cyprus and Greece refer to 2012.

Source: Eurostat 
The average share of liabilities of public corporations outside the scope of general government was almost 34\% of GDP (from 126.3\% of GDP in Germany to 1.6\% of GDP in Luxembourg). Significant liabilities of state-controlled corporations indicate that the European Commission should gradually expand the scope of the public debt to include the liabilities of all public sector controlled institutions, and not just those of general government.

Some states hold a significant amount of financial assets (stocks and shares) in public corporations and financial institutions. Therefore, it is reasonable to compare the value of financial assets with financial liabilities and calculate the total net financial liabilities of the state as a more credible indicator of the fiscal position. ${ }^{4}$

Public-private partnership. Fiscal risks for the state arise also from contingent liabilities associated with PPP projects. PPPs are complex, long-term contracts between two units, one of which is normally a corporation (or a group of corporations, private or public) called the operator or partner, and the other normally a government unit called the grantor. Total outstanding liabilities related to PPPs are recorded off-balance sheet of government and expressed in the adjusted capital value, which reflects the debt impact should the government have to take over the assets during the life of the contract. PPPs are used in the construction and maintenance of infrastructure facilities, but member states have not overused these arrangements, which only in a few states represent a significant fiscal risk. Thus, PPPs in Portugal and Cyprus accounted for about 5\%, whereas in Ireland, Hungary, the UK and Slovakia between I and 3\% of GDP in 2013. Germany extensively uses PPPs for the financing of capital projects, ${ }^{5}$ but it is - at the same time - the only member state for which data on PPPs are not available. However, PPP projects in Germany are recorded on the government's balance sheet, so there is no need to include them in the scope of potential liabilities.

\section{Figure 5}

Adjusted capital value of off-balance private-public partnerships in EU member states, 2013 (\% of GDP)

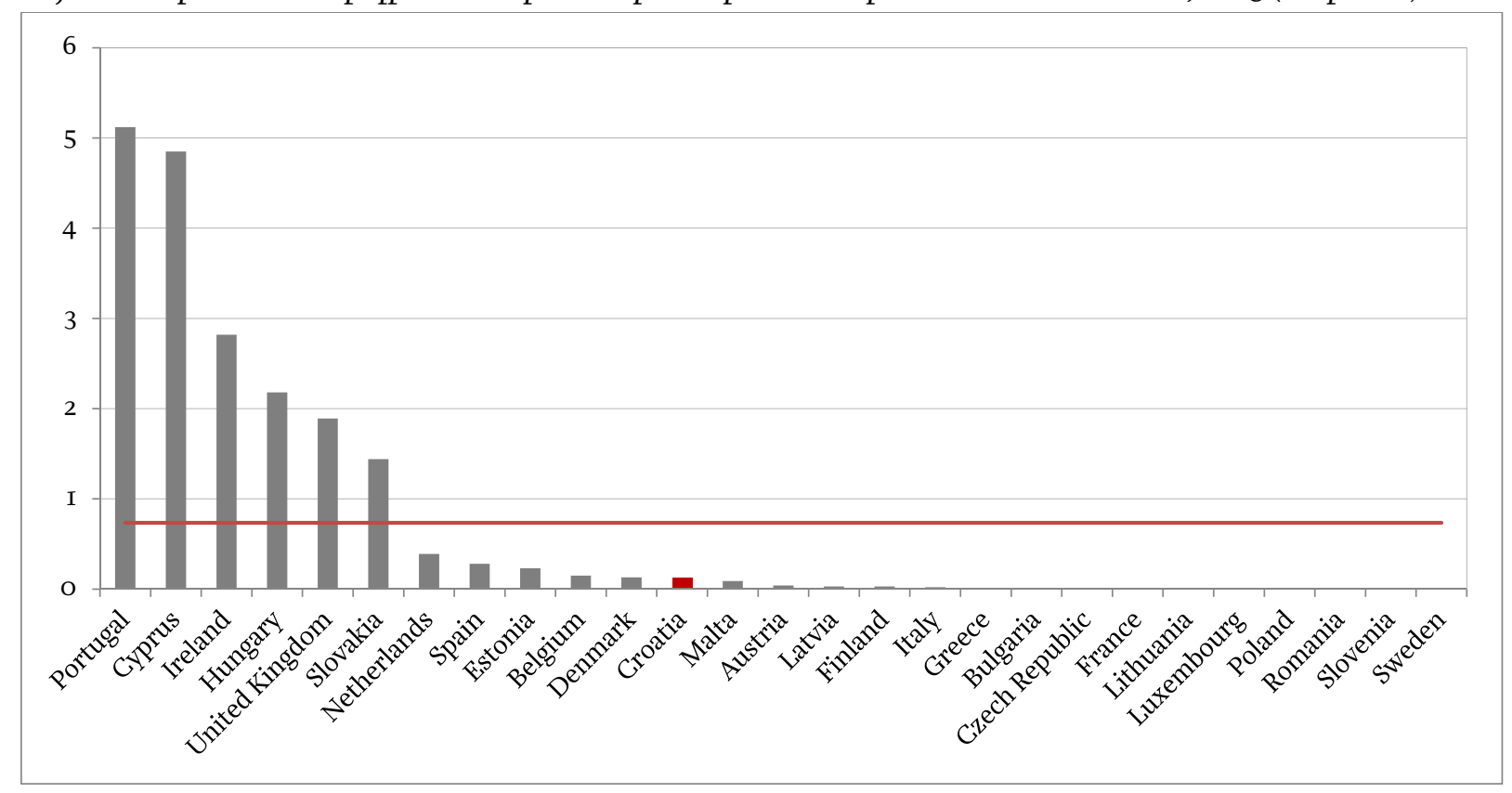

Source: Eurostat

${ }^{4}$ One of the following texts will be dedicated to state's financial assets.
${ }^{5}$ See: Bundesministerium der Finanzen (2008). 
Non-performing loans represent a potential threat to public finances if debtors who have received loans from the state face difficulties in repaying their loans. Those are generally loans given by the state to entities outside the public sector (for example, student loans). A loan is non-performing when payments of interest or principal are past due by 90 days or more, or interest payments equal to 90 days or more have been capitalized, refinanced, or delayed by agreement, or payments that are less than 90 days overdue but cannot confidently be expected to be made in full for various good reasons (such as a debtor filing for bankruptcy).

\section{Figure 6}

Stock of non-performing loans provided by government, 2013 (\% of GDP)

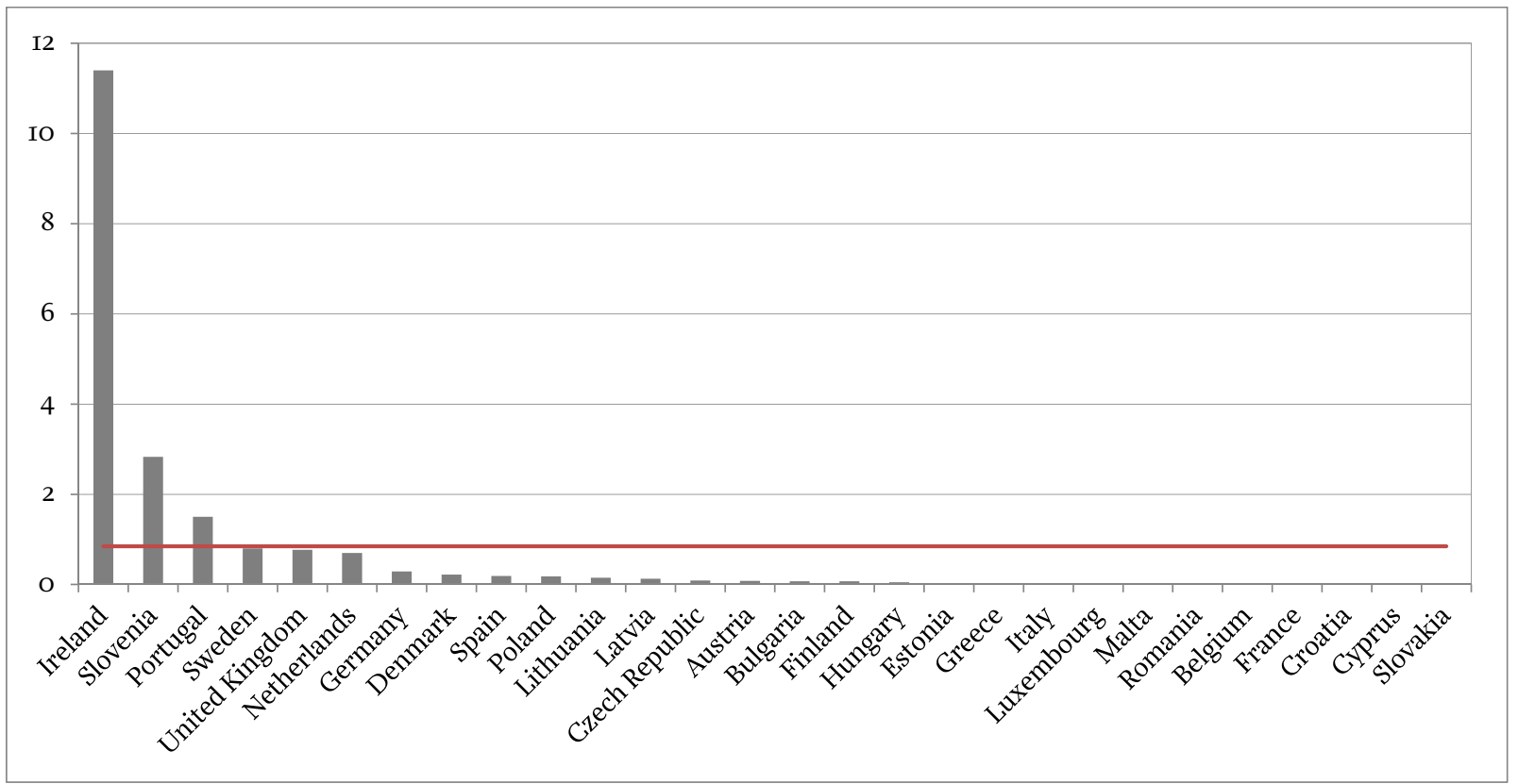

Source: Eurostat

A significant amount of non-performing loans (more than I\% of GDP) is present in Ireland, Slovenia and Portugal; in the case of Irish public finances, their stability is seriously endangered by the stock of nonperforming loans of II.4\% of GDP. These liabilities are largely related to the state-owned Irish Bank Resolution Corporation (IBRC), which was included in the scope of general government in 201 . Similarly, in Slovenia, most of the non-performing loans are related to the Bank Assets Management Company (BAMC) - a state-owned institution established in 2013 with the task of facilitating the restructuring of banks with systemic importance that were facing severe solvency and liquidity problems. It should be noted that a number of EU member states have, during the financial crisis, been exposed to risks related to the operations of banks, which they coped with either by remediation or by conversion of liabilities into equity. Until 2015, Croatia has been one of the few countries that have not had problems with contingent liabilities related to banks, but mainly with the liabilities of shipyards. The total cost of the rehabilitation of shipyards from 1992 to 2017 amounted to HRK 30.6bn (HRK 28.3bn from 1992 to 2012 and HRK 2.3bn from 2OI3 to 2017).

Total contingent liabilities of member states in 2013 are significant, averaging about $46 \%$ of GDP. The highest amount was recorded in Germany (almost I45\% of GDP), and the lowest in Slovakia (just slightly over $5 \%$ of GDP). Croatia was in the same year exposed to contingent liabilities amounting to around $23 \%$ of GDP, which is far below the EU average. However, the share of debt (both direct and indirect) to GDP is not the only criterion for assessing the financial stability of the country. Indeed, the stock of public debt in some countries is much higher than GDP, which does not affect their financial stability (e.g. Japan). On the other hand, in some countries with lower levels of GDP, even lower levels of debt can cause serious repayment difficulties (e.g. Croatia and Slovenia). 


\section{Figure 7}

Total stock of contingent liabilities of EU member states, 2013 (\% of GDP)

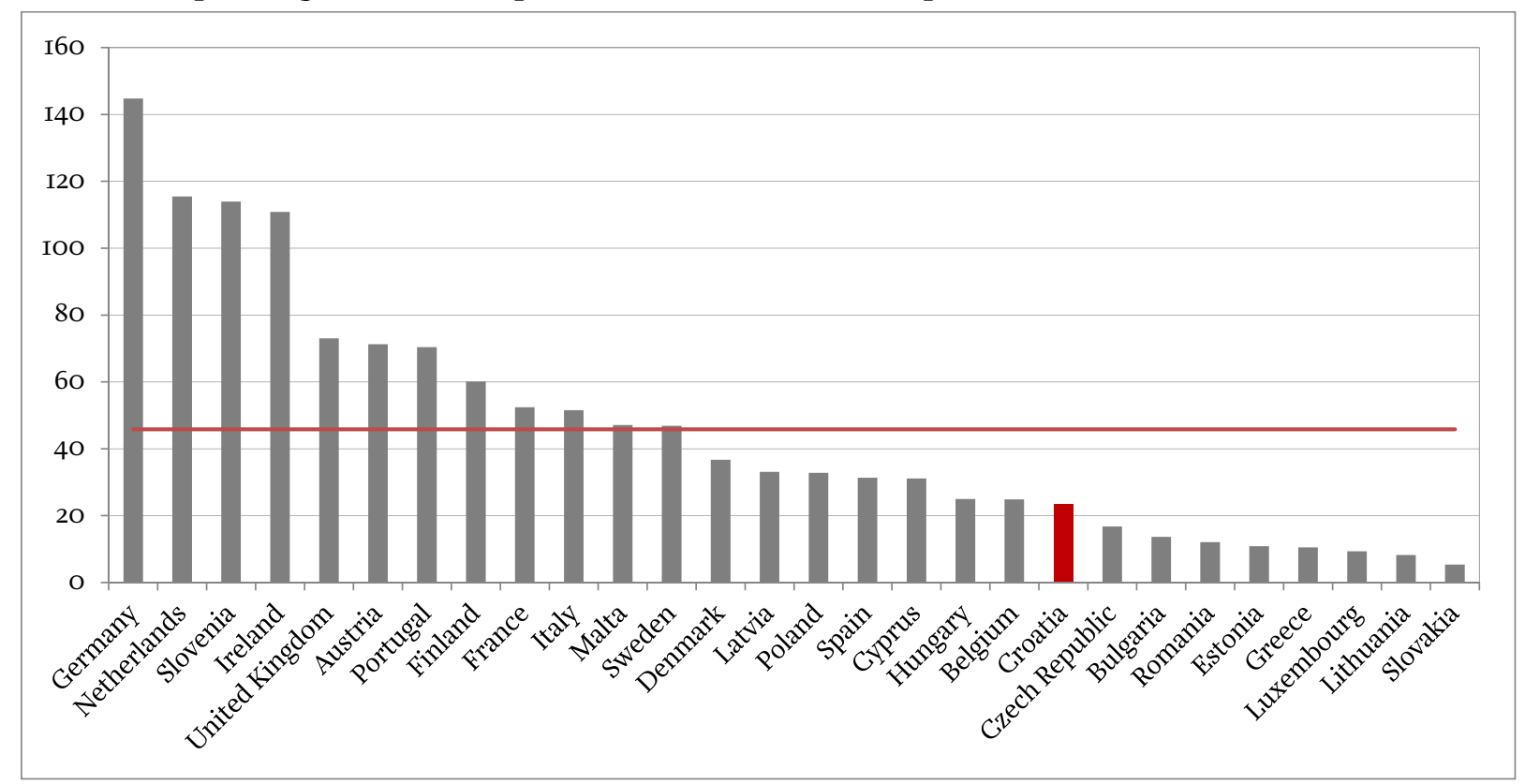

Source: Eurostat

\section{TOTAL (DIREGT AND CONTINGENT) DEBT OF EU MEMBER STATES}

Data on total - direct and contingent - debt reveal the real "fiscal vulnerability" of a country. The ratio of average total liabilities to GDP of EU member states in 2013 amounted to about II8\%. Only a few countries - Slovakia, Romania, Lithuania, Luxembourg, Bulgaria and Estonia - would meet the current fiscal criterion if the scope of public debt was extended (share of total debt to GDP below 60\%).

\section{Figure 8}

Total direct and contingent liabilities of EU member states, 2013 (\% of GDP)

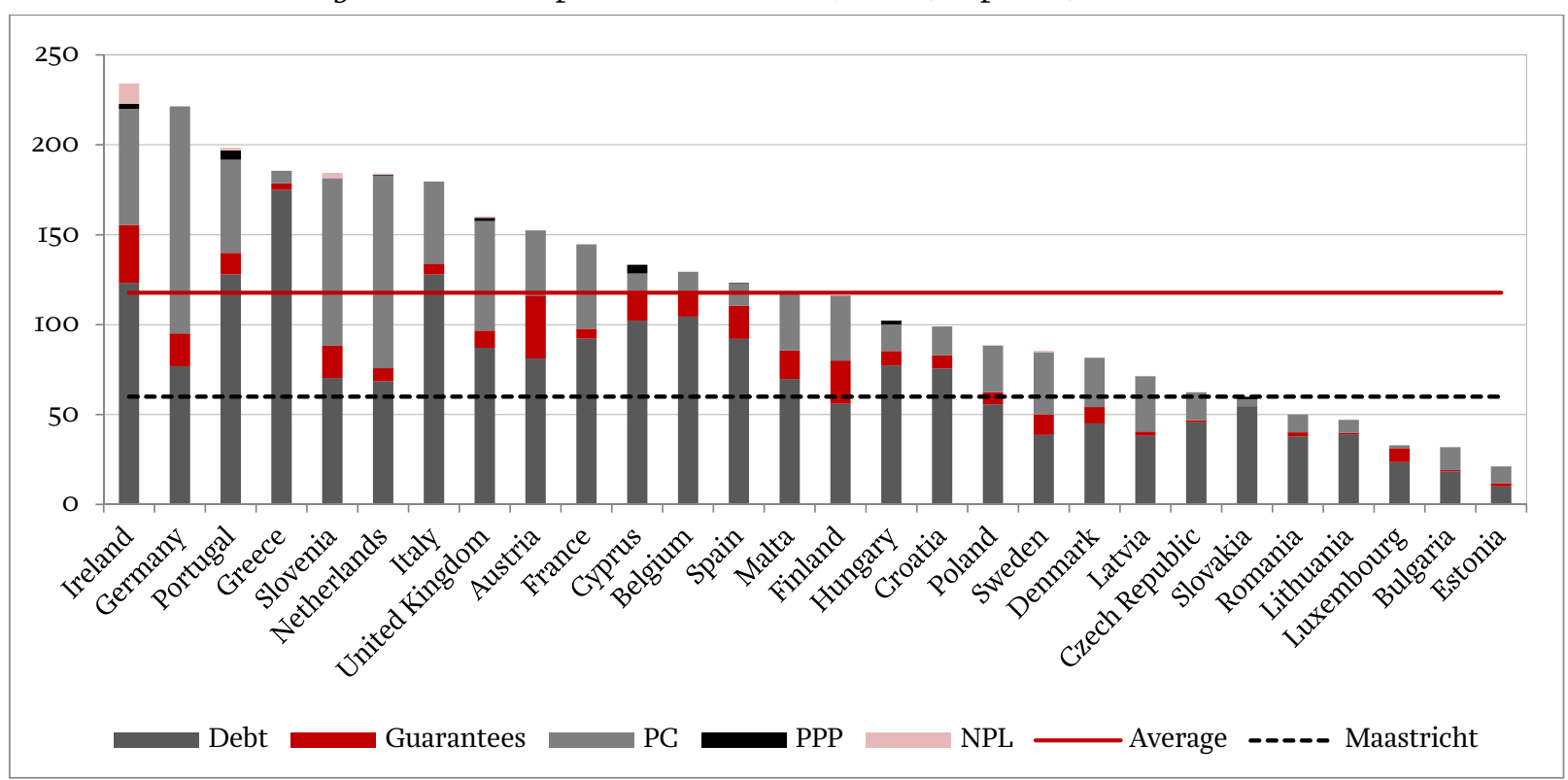

Note: PC - liabilities of public corporations, NPL - non-performing loans.

Source: Eurostat 
The stock of total public debt in Ireland and Germany is almost four times higher than the maximum amount of debt allowed by the Maastricht criteria. Such a conclusion can be reached by observing the total liabilities of the public sector, without any insight into the financial assets. However, it should be noted that in certain countries most of the liabilities relate to deposits of state-controlled banks. ${ }^{6}$ These deposits are recorded in the balance sheets of financial institutions as liabilities. However, the amount of assets (net debt) is - for statistical purposes - not taken into account. This finding further confirms the need to examine the overall financial position of the public sector when evaluating the indebtedness of countries. Instead of focusing on the gross debt (the sum of all liabilities), countries should focus on the net debt (the difference between financial liabilities and financial assets). The net debt should become a standard fiscal indicator that would gradually complement the - now quite outdated - Maastricht criteria.

\section{CONGLUSION}

Eurostat data on the contingent liabilities of EU member states reveal a completely different picture of their exposure to fiscal risks. This could in turn alter the perception of investors and rating agencies and encourage them to reconsider the ratings of certain countries, which might have an impact on their borrowing costs. However, there are four key reasons why data on contingent liabilities in this paper should be interpreted with caution:

- Data are specific to individual countries because of the close connection with their economic, financial and legislative (legal) structure.

- The coverage is not complete for all member states, whereas for some states it is doubtful (as shown in the appendix). This especially holds for liabilities of public corporations that are difficult to compare, because data for some countries are incomplete (not including liabilities of financial institutions and/or liabilities of entities controlled by the local government).

- Data on liabilities of public corporations are not consolidated, so part of these liabilities may refer to transactions with related parties.

- Data relate to gross liabilities (ignoring the asset value), which is particularly important for financial institutions that have significant amounts of assets and liabilities. In addition, for some member states, most of the liabilities of financial institutions refer to deposits.

The data published by Eurostat show the European Commission's willingness for and commitment to greater transparency, an increase of accountability for prudent management and coordination of fiscal policies among member states, but also at the EU level. The disclosure of contingent liabilities is a bold move of the Commission and the member states, which emphasises their desire to mitigate and eliminate potential fiscal shocks. With this release, the Commission has "opened the door" to the key issues of the management of fiscal risks and the prevention of their occurrence. Apparently, the EU will in the future devote more and more attention to the biggest causes of contingent liabilities - stateowned corporations and financial institutions and commercial banks.

${ }^{6}$ For example, more than half of the total amount of liabilities in the Netherlands is a result of the nationalization of two financial institutions (in 2009 and 2013). 
APPENDIX

State specific notes on the availability of data

\begin{tabular}{|c|c|}
\hline Country & Note \\
\hline Belgium & $\begin{array}{l}\text { Data not available for standardised guarantees. In the context of liabilities of public corporations, the } \\
\text { coverage for local government is not exhaustive, whereas the liabilities of public corporations involved in } \\
\text { financial activities are not available. }\end{array}$ \\
\hline Denmark & Data not available for standardised guarantees of local government. \\
\hline Germany & $\begin{array}{l}\text { Data on liabilities of public corporations refer to the value of liabilities as reported in their end-2oI2 balance } \\
\text { sheets. A significant amount of liabilities concerns deposits of public banks under government control. }\end{array}$ \\
\hline Ireland & $\begin{array}{l}\text { Adjusted capital value in PPP is calculated as contractual capital value less payments to date. Data on liabiliti } \\
\text { of certain public corporations refer to 2OI2. Additionally, data cover only public corporations controlled by tl } \\
\text { central government. The figure on non-performing loans is related to the inclusion of the Irish Bar } \\
\text { Resolution Corporation (IBRC) into the general government sector in 2OII. }\end{array}$ \\
\hline Greece & $\begin{array}{l}\text { Data on liabilities of public corporations are not exhaustive. They cover only central government sector } \\
\text { and refer to 20I2. A few units controlled by central government are under investigation and are not } \\
\text { included. The liabilities of public corporations involved in financial activities are not reported due to the } \\
\text { fact that these institutions received significant financial support from the Greek government and therefore } \\
\text { the extent to which government is controlling these entities is still under investigation. }\end{array}$ \\
\hline Spain & Data not available for standardised guarantees and non-performing loans for local government. \\
\hline France & Data on guarantees only available for central government. \\
\hline Croatia & Data not available for standardised guarantees and guarantees of the local government subsector. \\
\hline Italy & $\begin{array}{l}\text { Data on liabilities of public corporations refer to } 2013 \text { and exceptionally to } 2012 \text { or } 2011 \text {. Data on non- } \\
\text { performing loans not available for local government and social security funds. }\end{array}$ \\
\hline Cyprus & $\begin{array}{l}\text { Data on liabilities of public corporations refer to 20I2. Data reported are not exhaustive. Data for some } \\
\text { public corporations are not available and the liabilities of public corporations involved in financial activities } \\
\text { are not included. }\end{array}$ \\
\hline Luxembourg & $\begin{array}{l}\text { Data on liabilities of public corporations do not include the liabilities of public corporations involved in } \\
\text { financial activities. }\end{array}$ \\
\hline Malta & $\begin{array}{l}\text { The reported value for PPP is the contractual value. Data on liabilities of public corporations do not include } \\
\text { public corporations controlled by the local government sector. }\end{array}$ \\
\hline \multirow{2}{*}{ Netherlands } & $\begin{array}{l}\text { The significant amount of liabilities of public corporations concerns financial institutions under } \\
\text { government control. }\end{array}$ \\
\hline & $\begin{array}{l}\text { More than half of the amount is a consequence of the nationalization of two financial institutions (in } 2009 \\
\text { and 2013). }\end{array}$ \\
\hline Austria & $\begin{array}{l}\text { Data on PPP not available for central government. Data for liabilities of public corporations and quasi- } \\
\text { corporations generally refer to } 2 \mathrm{OI} 2 \text {. }\end{array}$ \\
\hline Poland & $\begin{array}{l}\text { Data not available for standardised guarantees of local government. Data on liabilities of public } \\
\text { corporations do not include small units (i.e. employing less than ro persons). }\end{array}$ \\
\hline Portugal & Data not available for standardised guarantees. \\
\hline Slovenia & $\begin{array}{l}\text { Data on guarantees not available for local government. The majority of non-performing loans refer to loans } \\
\text { of the DUTB (bad bank). The significant amount of liabilities of public corporations concerns deposits of } \\
\text { public banks under government control. }\end{array}$ \\
\hline Finland & Data on non-performing loans not available for local government and social security funds. \\
\hline UK & Data on PPP not available for local government. \\
\hline
\end{tabular}

Source: Eurostat

\section{LITERATURE}

Bundesministerium der Finanzen, 2008. The market for Public-Private Partnership in Germany.

Council Directive 20II/85/EU on requirements for budgetary frameworks of the Member States. Official Journal of the European Union, L 306/4I.

Council Regulation (EC) No 479/2009 on the application of the Protocol on the Excessive Deficit Procedure annexed to the Treaty Establishing the European Community. Official Journal of the European Union, L I45/I. 
Council Regulation (EU) No II77/2OII amending Regulation (EC) No 1467/97 on speeding up and clarifying the implementation of the excessive deficit procedure. Official Journal of the European Union, L 306/33.

Eurostat, 20I5. First time release of data on contingent liabilities and non-performing loans in EU Member States. News release, 26/2015.

Regulation (EU) No II76/2OII of the European Parliament and of the Council on the prevention and correction of macroeconomic imbalances. Official Journal of the European Union, L 306/25.

Regulation (EU) No II75/2OII of the European Parliament and of the Council amending Regulation (EC) No I466/97 on the strengthening of the surveillance of budgetary positions and the surveillance and coordination of economic policies. Official Journal of the European Union, L 306/12.

Regulation (EU) No II74/2OII of the European Parliament and of the Council on enforcement measures to correct excessive macroeconomic imbalances in the euro area. Official Journal of the European Union, L 306/8.

Regulation (EU) No II73/2OII of the European Parliament and of the Council on the effective enforcement of budgetary surveillance in the euro area. Official Journal of the European Union, L 306/I. 